\title{
Pengaruh Pelatihan Quantum Learning Terhadap Minat Belajar Ilmu Pengetahuan Alam Pada Siswa Sekolah Dasar
}

\author{
Nadea Zulfa Khairunnisa \\ R Rachmy Diana ${ }^{1}$ \\ Program Studi Psikologi \\ Universitas Islam Negeri Sunan Kalijaga Yogyakarta
}

\begin{abstract}
This study aims to examine the influence of quantum learning training on increasing interest in science learning to students. Subjects in this study were 8 students of class IV SD Negeri Ponjong II Gunungkidul Daerah Istimewa Yogyakarta with less learning interest in science subject. The data was analized by a scale of interest in learning science subject with GUTMANN scale model compiled by researchers. Experimental designed employed was pretest - posttest control group design. Subject in this study was randomly divided in two group, experiment group and control group that consist of 4 subjects in each groups. Mann Whitney $U$ was used to analize the differences between the pretest, posttest, and follow up from gained score. The result of score analysis pretest - posttest was 0,021 and pretest - follow up score was 0,020 ( $p<0,05)$, mean rank of experiment group was 6,50 and mean rank of controlt group was 2,50 which indicated that experiment group has a higher level of interest in learning science. This showed that quantum learning training could increase student's interest in learning science subject at SD Negeri Ponjong II Gunungkidul Daerah Istimewa Yogyakarta.
\end{abstract}

Keywords: Interest in Learning, Quantum learning Training, School-Age Children

\begin{abstract}
ABSTRAK: Penelitian ini bertujuan mengetahui pengaruh pelatihan quantum learning terhadap peningkatan minat belajar IPA pada siswa. Subjek dalam penelitian ini melibatkan 8 siswa kelas IV Sekolah Dasar Negeri (SDN) Ponjong II Gunungkidul, Daerah Istimewa Yogyakarta, yang memiliki minat belajar rendah pada pelajaran IPA. Pengumpulan data menggunakan skala minat belajar IPA dari GUTMANN yang disusun sendiri peneliti. Desain eksperimen menggunakan pretest-posttest control group design. Subjek pada penelitian ini dibagi secara acak ke dalam dua kelompok, eksperimen dan kontrol yang terdiri dari 4 subjek pada setiap kelompok. Mann Whitney U digunakan untuk menganalis perbedaan antara prates, pascates, dan tes tindak lanjut. Skor hasil analisis prates-pascates adalah 0,021 dan skor prates-tindak lanut adalah 0,020 (p < $0,055)$, mean rank kelompok eksperimen memperoleh skor 6,50 sedangkan mean rank kelompok kontrol adalah 2,50 yang menunjukkan bahwa kelompok eksperimen mempunyai tingkat minat belajar yang lebih tinggi daripada kelompok kontrol. Hal ini menunjukkan bahwa pelatihan quantum learning dapat meningkatkan minat belajar IPA pada siswa kelas IV di SD Negeri Ponjong II Gunungkidul Daerah Istimewa Yogyakarta.
\end{abstract}

Kata Kunci : Pelatihan Quantum learning, Minat Belajar, Anak Usia Sekolah

\footnotetext{
${ }^{1}$ Korespondensi mengenai isi artikel ini dapat dilakukan melalui: rachmydiana01@gmail.com
} 
Pendidikan merupakan sarana untuk mengembangkan kualitas sumber daya manusia. Melalui pendidikan diharapkan mampu mencetak generasi yang berkualitas sehingga dapat berkontribusi dalam rangka mendukung tercapainya pembangunan Nasional dan kemajuan bangsa. Untuk maksud tersebut, Kementerian Pendidikan dan Kebudayaan RI mewujudkannya melalui sebuah kurikulum.

Pemerintah pada saat ini memberlakukan dua kurikulum, yaitu kurikulum 2013 dan kurikulum KTSP. Sekolah Dasar (SD) Negeri Ponjong II Gunungkidul kebetulan menerapkan kurikulum KTSP. Undang-undang No. 20 tahun 2003 pasal 37 ayat 1 mengatur tentang KTSP dan memuat 10 mata pelajaran yang wajib dilaksanakan pada jenjang Sekolah Dasar. Salah satu mata pelajaran yang wajib dilaksakan adalah Ilmu Pengetahuan Alam (IPA) .

Mata pelajaran IPA adalah pengetahuan yang melibatkan observasi, eksperimentasi, penyimpulan, penyusunan teori yang saling berkaitan satu sama lain. Mata pelajaran IPA sangat berperan dalam perkembangan IPTEK, karena mata pelajaran IPA berisi pengetahuan mengenai alam semesta yang meliputi manusia, tumbuhan, hewan, maupun komponen biotik dan abiotik. Pelajaran IPA akan memperkaya bekal pengetahuan yang nantinya akan berguna bagi kehidupan (Abdullah, 1998).

Namun mata pelajaran yang dinilai penting ini tidak diimbangi dengan pencapaian minat belajar. Data yang diperoleh dari surat kabar Tribun (10/06/2017) menunjukkan bahwa nilai US (Ujian Sekolah) untuk mata pelajaran IPA di Daerah Istimewa Yogyakarta (DIY) pada jenjang Sekolah Dasar (SD) dan MI (Madrasah Ibtidaiyah) mengalami penurunan. Nilai rata-rata siswa pada tahun 2016 mencapai 263,82, sementara tahun
2017, nilai rata-rata US hanya sebesar 217,1. Daerah yang mengalami penurunan terutama Kabupaten Gunungkidul. Nilai US di Gunungkidul juga termasuk paling rendah dibandingkan dengan Kabupaten lain di DIY.

Salah satu sekolah di Gunungkidul yang tergolong punya nilai rendah adalah SD Ponjong II Gunungkidul. Nilai US di SD ini paling rendah terutama pada matapelajaran IPA. Sebesar $75 \%$ siswa memperoleh nilai IPA dibawah 65, padahal Kriteria Ketuntasan Minimal (KKM) untuk mata pelajaran IPA adalah sebesar 75 .

Hasil wawancara dengan lima siswa dan tiga guru di SD Ponjong tersebut diperoleh informasi bahwa pelajaran IPA dianggap sulit terutama bagi siswa kelas empat. Ketika guru bertanya kepada siswa mengenai materi pelajaran yang baru saja disampaikan, banyak siswa yang tidak bisa menjawab. Siswa mengaku bosan dan sering merasa mengantuk. Saat hendak mengikuti pelajaran pun mereka mengaku tidak bersemangat sehingga sering lupa membawa buku pelajaran. Hal ini mengindikasikan bahwa minat belajar siswa terhadap mata pelajaran IPA di SD Ponjong itu rendah.

Metode pembelajaran konvensional cenderung membuat siswa menjadi bosan dan mengalami kesulitan belajar karena materi yang disampaikan guru tidak dapat dipahami dengan baik. Hal ini berdampak pada rendahnya minat belajar siswa pada mata pelajaran IPA. Salah satu faktor yang mempengaruhi kesulitan belajar siswa adalah minat belajar (Arisetiawan, 2013). Hurlock (2005) menyatakan bahwa minat adalah sumber motivasi yang mendorong seseorang untuk melakukan apa yang mereka inginkan. Apabila siswa memiliki minat belajar tinggi maka akan berusaha lebih keras untuk dapat meraih prestasi dibandingkan siswa yang minat belajarnya rendah. 
Dapat disimpulkan bahwa minat belajar adalah suatu ketertarikan dalam belajar yang dilakukan individu terhadap pelajaran tertentu sehingga menimbulkan perubahan tingkah laku (baru) berupa keterlibatan secara aktif untuk mengikuti kegiatan belajar atas dasar kesadaran dalam usahanya memenuhi kebutuhan. Aspekaspek yang terdapat dalam minat belajar antara lain adalah ketertarikan, perhatian, kesadaran, dan konsentrasi (Crow dan Crow, 1994). Sementara faktor yang mempengaruhi minat belajar siswa dapat dibedakan menjadi dua, yaitu; faktor internal dan eksternal. Faktor internal berasal dari individu itu sendiri. Faktor eksternal berasal dari lingkungan keluarga atau keadaan rumah tangga, cara mengajar guru, serta alat-alat yang digunakan dalam belajar mengajar (Purwanto dalam Hamalik, 2012).

Metode belajar merupakan salah satu faktor eksternal yang mempengaruhi minat belajar. Metode pembelajaran dapat diartikan sebagai cara penyampaian materi oleh pendidik kepada peserta didik agar terjadi proses pembelajaran pada diri peserta didik sebagai upaya untuk mencapai tujuan yang diharapkan. Pembelajaran yang baik adalah pembelajaran yang efektif, aktif, serta menyenangkan. Dengan adanya lingkungan yang kondusif untuk belajar, maka siswa akan dapat belajar secara optimal (Sutikno, 2009). Belajar itu sendiri didefinisikan sebagai aktivitas atau suatu proses untuk memperoleh pengetahuan, meningkatkan keterampilan, memperkokoh kepribadian, dan memperbaiki sikap dan perilaku (Suryono, 2011).

Salah satu metode belajar yang memungkinkan siswa dapat belajar secara maksimal adalah quantum learning. Metode quantum learning merupakan strategi pembelajaran yang dapat mempertajam pemahaman dan daya ingat, serta membuat belajar sebagai suatu proses yang menyenangkan dan bermanfaat bagi siswa
(Porter dan Hernacki, 2013). Quantum learning menuntut adanya kebebasan, proses belajar yang menyenangkan sekaligus menggairahkan bagi siswa. Adapun aspek-aspek quantum learning antara lain: kekuatan AMBaK (Apa Manfaat BagiKu), penataan lingkungan belajar, memupuk sikap juara, membebaskan gaya belajar, membiasakan siswa mencatat, membiasakan membaca, menjadikan anak lebih kreatif, dan melatih kekuatan memori anak (Hernacki dan DePorter, 2013).

Penelitian ini menggunakan metode quantum learning dalam bentuk pelatihan. Pelatihan disini dipahami sebagai pengalaman pembelajaran dalam mencari perubahan permanen secara relatif pada individu yang akan memperbaiki kemampuan dalam melakukan pekerjaan tersebut (DeCenzo dan Robin, 1999).

Rumusan masalah yang menjadi kajian penelitian ini: "Apakah Pelatihan Quantum Learning Berpengaruh terhadap Peningkatan Minat Belajar IPA pada Siswa Kelas IV SD Negeri Ponjong II Gunungkidul, Daerah Istimewa Yogyakarta?"

\section{METODE PENELITIAN}

\section{Desain Eksperimen}

Penelitian ini menggunakan metode eksperimen. Desain eksperimennya pretestpostest control group design. Desain eksperimen pretest-postest control group design memiliki dua tipe rancangan yaitu random-pretest (RO) dan tipe pretestrandom (OR). Pada tipe RO randomisasi dilakukan setelah prates, sedangkan pada tipe OR prates dilakukan sebelum randomisasi. Adapun pengaruh perlakuan disimbolkan dengan ( ) - ( - ). Apabila terdapat perbedaan yang signifikan antara kelompok ekperimen dan kelompok kontrol, berarti perlakuan yang diberikan berpengaruh secara signifikan (Latipun, 2011). Adapun desain dalam penelitian dapat dilihat pada tabel berikut: 
Tabel. 1 Bentuk Rancangan Eksperimen

Keterangan :

\begin{tabular}{|llll|}
\hline $\mathrm{R}$ & $\mathrm{O} 1$ & $\mathrm{X}$ & 02 \\
$\mathrm{R}$ & 03 & & 04 \\
\hline
\end{tabular}

$\mathrm{R}=$ Kelompok yang dipilih secara random

$\mathrm{X}=$ perlakuan

$01=$ hasil prates kelompok eksperimen

02 = hasil prates kelompok kontrol

03 =hasil pascates kelompok eksperimen

04 = hasil pascates kelompok kontrol

\section{Subjek Penelitian}

Populasi yang terdapat dalam penelitian ini adalah siswa kelas IV SD Negeri Ponjong II Kabupaten Gunungkidul Daerah Istimewa Yogyakarta. Adapun untuk sampel penelitian adalah siswa kelas IV yang mempunyai indikator minat belajar rendah yang diketahui berdasarkan hasil try out skala minat belajar yang digunakan sekaligus sebagai prates.

\section{Metode Pengambilan Data}

Pengambilan data dalam pelatihan ini dilakukan dua kali, yaitu prates dan pascates dengan menggunakan skala. Skala adalah alat ukur psikologis dalam bentuk kumpulan pernyataan sikap yang disusun sedemikian rupa sehingga pernyataan dari respon seseorang dapat diberi skor kemudian diinterpretasikan (Azwar, 2008).

Skala yang digunakan dalam penelitian ini disusun berdasarkan aspekaspek minat belajar yang dikemukakan Crow dan Crow (1994). Penilaian skala minat belajar penelitian ini menggunakan skala GUTMANN yang terdiri dari dua alternatif jawaban. Jawaban yang diberikan yaitu Setuju (S), dan tidak setuju (TS). Skala ini disusun dengan mengelompokkan aitemaitem favorable dan unfavorable (Supratiknya, 2014) yang diberikan untuk aitem-aitem favorable adalah "Setuju (S)" skor 1 sedangkan "Tidak Sesuai (TS)" dengan skor 0. Sedangkan alternative jawaban terhadap skor yang diberikan untuk aitem-aitem unfavorable adalah "Setuju (S)" skor 0 sedangkan "Tidak Sesuai (TS) skor 1". Semakin tinggi skor yang diperoleh dari skala minat belajar menunjukkan semakin tinggi minat belajar seseorang. Hasil uji coba menunjukkan bahwa koefisien alpha skala minat belajar adalah 0,953 .

\section{Prosedur Intervensi}

Prosedur penelitian meliputi tahap persiapan, pelaksanaan, dan tahap analisis data. Tahap persiapan meliputi perizinan kepada pihak sekolah, persiapan alat ukur penelitian, penyusunan modul pelatihan, TFT (Training For Trainer), dan try out modul pelatihan yang dilaksanakan selama 3 hari dari tanggal 5 sampai 7 oktober 2017, di ruang RRC SD Ponjong II Gunungkidul. Proses pelaksanaan meliputi prates pascates, pelaksanaan pelatihan selama tiga hari pada kelompok eksperimen yaitu pada tanggal 12 sampai 14 Oktober 2017 kemudian diakhiri dengan pengambilan data tindak lanjut. 


\section{HASIL PENELITIAN}

\section{Deskripsi Data}

Pengambilan data prates dilakukan pada tanggal 2 Oktober 2017 di ruangan kelas empat SD Negeri Ponjong II Gunungkidul. Pengambilan data prates ini bersamaan dengan try out skala, atau menggunakan tryout terpakai. Berdasarkan hasil prates, diketahui kelompok eksperimen, berjumlah 4 subjek, berkategori rendah yaitu VN, IZ, dan LA, dan NI $(X<11,3)$. Pada kelompok kontrol keseluruhan subjek yaitu RZ, FI ZN, dan IH juga berada pada kategori rendah $(X<11,3)$. Langkah selanjutnya adalah memberi perlakuan berupa pelatihan quantum learning pada kelompok eksperimen. Setelah pelatihan dilanjutkan pengujian atau pascates. Hasil kategorisasi pascates skala minat belajar IPA pada kelompok eksperimen yaitu VN, IZ, dan LA, dan NI menjadi kategorisasi sedang $(11,3 \leq \mathrm{X} \leq$ 22,7). Sementara pada kelompok kontrol tetap berada pada kategori rendah (X 11,3).

\section{Hasil Uji Hipotesis}

Tabel.2 Hasil Uji Analisis Mann Whitney U Prates dan Pascates

\begin{tabular}{|c|c|c|c|}
\hline Nilai Mann - Whitney $U$ & Sig & $\mathrm{Z}$ & Keterangan \\
\hline 0,000 & 0,021 & $-2,309$ & $\mathrm{P}<0,05$ \\
\hline
\end{tabular}

Berdasarkan hasil uji analisis Mann Whitney U diketahui terjadi peningkatan minat belajar IPA setelah diberikan pelatihan quantum learning dengan nilai signifikansi sebesar $0,021(\mathrm{p}<0,05)$. Hal ini menunjukkan adanya perbedaan yang signifikan antara sebelum dan sesudah diberikannya perlakuan pada kelompok eksperimen. Secara keseluruhan kelompok eksperimen mengalami peningkatan poin dilihat dari perbandingan prates dan pascates.

Tabel. 3 Gain score kelompok eksperimen dan kelompok kontrol

\begin{tabular}{c|c|c|c|c}
\hline \multicolumn{5}{c}{ Kelompok Eksperimen } \\
\hline No & Nama & prates & pascates & Gain-score \\
\hline 1. & VN & 11 & 21 & 10 \\
\hline 2. & NI & 10 & 19 & 9 \\
\hline 3. & IZ & 11 & 22 & 11 \\
\hline 4. & LA & 9 & 17 & 8 \\
\hline \multicolumn{5}{|c|}{ Kelompok Kontrol } \\
\hline No & Nama & prates & pascates & Gain-score \\
\hline 1. & RZ & 9 & 12 & 3 \\
\hline 2. & FI & 11 & 9 & -2 \\
\hline 3. & ZN & 7 & 11 & 4 \\
\hline 4. & IH & 10 & 11 & 1 \\
\hline
\end{tabular}

Diketahui bahwa pelatihan quantum learning efektif dalam meningkatkan minat belajar IPA. Dengan demikian, hipotesis yang diajukan terbukti. Berdasarkan data tindak lanjut juga masih ada pengaruh pemberian pelatihan quantum learning terhadap peningkatan minat belajar IPA, dimana subjek kelompok eksperimen berada pada kategori sedang, yaitu VA, NI, IZ, dan LA. Pada kelompok kontrol yaitu subjek 
FK, ZN, dan IH memiliki kategorisasi rendah dan hanya subjek RZ mengalami peningkatan skor sehIngga berada pada kategorisasi sedang.

\section{PEMBAHASAN}

Tujuan penelitian ini adalah mengetahui sejauhmana efektivitas pelatihan quantum learning dapat meningkatkan minat belajar IPA pada siswa Sekolah Dasar. Berdasarkan hasil analisis data, diketahui bahwa pelatihan quantum learning dapat meningkatkan minat belajar IPA khususnya di SD Negeri Ponjong II Gunungkidul. Selain itu, berdasarkan hasil gain score prates dan pascates yang diperoleh dari hasil akumulasi skor minat belajar antara kelompok eksperimen dengan kelompok kontrol diketahui jumlah gain score pada kelompok eksperimen lebih besar apabila dibandingkan dengan kelompok kontrol.

Hasil prates pada kelompok eksperimen berada pada kategorisasi rendah. Pasca diberikan perlakuan berupa pelatihan quantum learning perolehan skor berdasarkan skala minat belajar IPA mengalami kenaikan menjadi kategori sedang. Hasil prates pada kelompok kontrol pada pengukuran kedua tetap berada pada kategori rendah. Pada kelompok eksperimen, terdapat peningkatan skor antara 8 sampai 11 poin, sedangkan kelompok kontrol terdapat tiga subjek yang mengalami kenaikan skor 1 sampai 3 poin serta satu subjek yang mengalami penurunan satu poin. Meskipun kedua kelompok sama-sama mengalami peningkatan, akan tetapi kenaikan skor subjek pada kelompok kontrol tidak signifikan jumlahnya.

Pada saat pelaksanaan pelatihan, peneliti menggunakan acuan aspek-aspek quantum learning yang dikemukakan Hernacki dan DePorter (2013), antara lain: kekuatan AMBaK (Apa Manfaat BagiKu), penataan lingkungan belajar, memupuk sikap juara, membebaskan gaya belajar, membiasakan siswa mencatat, membiasakan membaca, menjadikan anak lebih kreatif, dan melatih kekuatan memori anak. Pelatihan quantum learning ini diharapkan dapat meningkatkan minat belajar IPA pada subjek setelah pelatihan selesai dilaksanakan. Aspek minat belajar disini mengacu berdasarkan teori Crow dan Crow (1994) yaitu ketertarikan, perhatian, konsentrasi, dan kesadaran.

Aspek pertama quantum learning adalah kekuatan AMBaK (Apa Manfaat BagiKu). Dengan mengetahui manfaat yang akan diperoleh dengan mempelajari sesuatu, maka siswa akan bersungguhsungguh untuk belajar (DePorter dan Hernacki, 2013). Penerapan konsep AMBaK (Apa Manfaat BagiKu) dilakukan pada setiap akan dimulainya belajar. Subjek diberi pemahaman mengenai manfaat apa saja yang bisa diperoleh ketika mempelajari materi tertentu.

Aspek quantum learning kedua adalah membiasakan siswa mencatat. Mencatat yang efektif sangat penting untuk membantu siswa dalam mengingat apa yang tersimpan dalam memori. Belajar akan mudah dipahami dengan baik ketika siswa tidak hanya menerima, melainkan dapat menuliskannya kembali dengan bahasa sendiri yang mudah dimengerti (DePorter dan Hernacki, 2013). Penerapan dari aspek kedua ini adalah menggunakan konsep mind-mapping sebagai salah satu teknik mencatat yang efektif. Konsep mindmapping menggunakan pengingatpengingat visual dan sensorik dari suatu pola atau ide-ide yang saling berkaitan sehingga memudahkan siswa untuk mengingat suatu informasi. Apabila anak sudah terbiasa membaca maka minat belajar pun akan tumbuh dengan sendirinya (DePorter dan Hernacki, 2013).

Aspek ketiga quantum learning adalah memupuk sikap juara dan melatih kekuatan memori anak. Memupuk sikap juara perlu dilakukan untuk meningkatkan 
semangat belajar siswa. Dengan menanamkan sikap juara maka akan menanamkan motivasi menuju sebuah keberhasilan. Penerapan dari aspek ini adalah melalui kuis yang dikemas dalam bentuk permainan seperti kuis "PolisiPolisi" pada pertemuan pertama, "Balonku ada Lima pada pertemuan kedua", "Permainan Temukan Aku " dan "Kuis Ranking 1" pada pertemuan ketiga. Kuis tersebut dikemas menyenangkan dimana setiap siswa akan diberikan reward apabila dapat menjawab soal dengan jawaban yang benar. Sedangkan apabila ada subjek yang salah menjawab pertanyaan, subjek tersebut tetap diberikan sugesti positif sehingga tidak akan merasa malu. Aspek ini juga diterapkan dengan memberikan sugesti positif kepada subjek yaitu berupa motivasi diri pada setiap pertemuan. Selama kegiatan, subjek diberikan penghargaan dalam setiap usahanya dengan memberikan pujian agar subjek memiliki sikap positif. Dengan sikap juara maka akan memupuk sikap positif dan siswa akan merasa lebih dihargai sehingga dapat menumbuhkan minat belajar siswa karena siswa nyaman dengan apa yang dipelajarinya (DePorter dan Hernacki, 2013).

Aspek keempat quantum learning adalah melatih kekuatan memori anak. Kekuatan memori anak perlu dilatih untuk mendapatkan memori yang baik karena sangat diperlukan untuk belajar. Semakin banyak indera yang dilibatkan dalam belajar, maka akan semakin bermakna dalam memahami suatu materi pelajaran. Penerapan dari aspek ini salah satunya adalah melalui kegiatan "Jalan-jalan Asik" yang dilakukan pada pertemuan pertama. Pada kegiatan tersebut subjek dapat belajar dengan dihadirkan objek secara langsung yaitu dengan cara observasi. Dengan menghadirkan situasi dan objek langsung untuk belajar maka suasana belajar akan lebih bermakna dan menyenangkan bagi siswa sehingga akan menumbuhkan minat belajar terhadap apa yang dipelajari (DePorter dan Hernacki, 2013).

Selain itu, aspek melatih kekuatan memori anak juga diwujudkan pada kegiatan "Menyimak Video Edukatif". Pada kegiatan tersebut subjek diberikan pemahaman-pemahaman dalam wujud penayangan video edukatif yang bertujuan agar pembelajaran lebih bermakna dan tidak membosankan. Terbukti bahwa kegiatan "Jalan-jalan Asik" dan "Menyimak Video Edukatif" dapat melatih kekuatan memori anak dikarenakan pada prosesnya melibatkan banyak indera ketika belajar. Penggunaan media pengajaran dalam proses belajar mengajar dapat membangkitkan motivasi dan stimulan belajar, membangkitkan keinginan dan minat belajar yang baru, serta dapat membawa pengaruh-pengaruh psikologis terhadap siswa (Hamalik, 1986).

Aspek kelima quantum learning adalah menjadikan anak lebih kreatif. Siswa yang kreatif adalah siswa yang intuitif, selalu ingin tahu, senang mencoba, dan suka bermain-main. Dengan adanya sikap kreatif ini maka akan memungkinkan siswa untuk memandang segala sesuatu dengan cara yang baru. Penerapan dari aspek ini adalah melalui kegiatan "Mengenal Rangka Manusia dengan Permainan Puzzle". Kegiatan tersebut berusaha memberi pemahaman kepada subjek tentang materi rangka manusia yang dikemas dengan cara yang menarik. Melalui kegiatan tersebut subjek dapat belajar sambil bermain sehingga dapat mendorong keingintahuan subjek untuk terus mencoba. Apabila anak senang mencoba maka anak akan menyukai hal-hal baru sehingga dapat membangkitkan minat terhadap apa yang dipelajarinya (DePorter dan Hernacki, 2013).

Selain itu, menjadikan anak lebih kreatif dapat diwujudkan melalui kegiatan "Belajar Rantai Makanan dengan Bermain Peran" yang dilakukan pada pertemuan pertama. Kegiatan tersebut merupakan 
penyampaian materi mengenai rantai makanan yang diwujudkan dalam bentuk bermain peran sehingga mendorong siswa untuk bersikap intuitif terhadap apa yang dipelajarinya. Pembelajaran yang dikemas dengan cara bermain akan menumbuhkan imajinasi sehingga dapat membangkitkan kreativitas anak. Kreativitas penting untuk dikembangkan dikarenakan apabila anak memiliki sikap kreatif maka akan terbiasa menghasilkan inovasi dengan pengetahuan yang dimilikinya. Mengemas kegiatan dengan cara yang menyenangkan dapat membangkitkan minat belajar siswa (DePorter dan Hernacki, 2013).

Aspek keenam quantum learning adalah membebaskan gaya belajar. Anak yang belajar sesuai dengan gaya belajarnya akan dapat menumbuhkan perasaan senang ketika belajar. Pada pelatihan ini, aspek membebaskan gaya belajar diterapkan melalui kegiatan yang dinamakan "Pohon Kebaikan". Pada kegiatan tersebut, subjek diberikan kesempatan untuk menuliskan harapan-harapan yang ingin dicapai dimasa mendatang serta menuliskan cara belajar yang disukai masing-masing subjek. Selama kegiatan, subjek diperbolehkan belajar dengan cara yang disukainya seperti halnya memperbolehkan subjek memainkan atau membunyikan pensilnya sebagai pembelajar dengan tipe kinestetik dan memfasilitasi subjek dengan gaya belajar lainnya seperti visual dan auditori. Sebagaimana yang dikemukakan Keefe (Sugihartono, 2007) bahwa gaya belajar berhubungan dengan cara anak belajar dan mengenai cara belajar yang disukai. Sebagai cara yang disukai, maka siswa akan sering menggunakannya karena merasa mudah dengan cara tersebut. Apabila seorang siswa telah merasa nyaman dan senang ketika belajar, maka akan membangkitkan minat belajar (DePorter dan Hernacki, 2013).

Aspek ketujuh quantum learning adalah penataan lingkungan belajar. Dalam proses kegiatan belajar mengajar diperlukan adanya lingkungan yang kondusif agar dapat membawa siswa pada perasaan senang dan nyaman dalam belajar. Aspek penataan lingkungan belajar ini diterapkan dengan memasang musik klasik selama pembelajaran, membagikan kartu motivasi kepada siswa, maupun mengatur ruang yang kondusif bagi siswa belajar. Sehingga dengan penataan lingkungan belajar yang tepat maka akan mencegah kebosanan saat pelajaran berlangsung. Lingkungan yang kondusif dapat menstimulus siswa untuk belajar secara maksimal sehingga dapat menumbuhkan minat belajar siswa (DePorter dan Hernacki, 2013).

Aspek terakhir quantum learning adalah membiasakan siswa membaca. Membaca adalah salah satu aktivitas yang penting dalam suatu pembelajaran. Dengan membaca maka akan menambah pemahaman, wawasan, serta perbendaharaan kata (DePorter, 2013). Penerapan dari aspek membiasakan membaca adalah dengan memberikan subjek materi bacaan dalam lembaran kertas untuk dibaca dirumah. Selain itu, aspek ini dapat juga diwujudkan melalui kegiatan mind-mapping dimana sebelum subjek mencatat diupayakan telah membaca terlebih dahulu tentang materi yang akan dituangkan dalam bentuk catatannya tersebut.

Untuk mencegah kebosanaan ketika belajar, pada setiap pertemuan dilengkapi dengan sesi ice breaking. Salah satu ice breaking yang diterapkan pada pelatihan ini adalah "goyang jari jempol" yaitu permainan yang melibatkan indera untuk berkonsentrasi maupun relaksasi. Secara keseluruhan, pada sesi ice breaking ini subjek terlihat senang dan antusias selama mengikuti kegiatan. Ice breaking merupakan permainan yang dapat mengubah suasana kebekuan kelompok atau mengubah situasi yang membosankan, mengantuk, menjenuhkan menjadi lebih rileks, menyenangkan, dan bersemangat ketika berada di kelas atau pun ruangan (Sunarto, 2012). Apabila 
kegiatan yang dilakukan menarik maka siswa akan tertarik dan senang sehingga dapat menumbuhkan minat belajar siswa (DePorter dan Hernacki, 2013).

Dari serangkaian kegiatan, terdapat beberapa kegiatan yang menggunakan lembar kerja atau worksheet yang digunakan subjek untuk menuangkan hasil kerjanya dalam bentuk tulisan ataupun gambar. Adapun manfaat worksheet atau lembar kerja yaitu bertujuan agar subjek mampu belajar pemecahan masalah. Sebagaimana yang dikemukakan Trinto (2013) bahwa lembar kerja atau lembar kegiatan dapat menjadi panduan untuk melatih pengembangan kognitif maupun aspek dari pembelajaran lainnya.

Terbuktinya hipotesis dalam penelitian ini (signifikan) menunjukkan bahwa pelatihan quantum learning berpengaruh terhadap peningkatan minat belajar IPA siswa. Penelitian lain yang dilakukan Hasan dan Soerjono (2014) menunjukkan bahwa menerapkan quantum learning lingkungan kondusif dapat meningkatkan minat belajar siswa terhadap mata pelajaran matematika. Sesuai teori yang dikemukakan DePorter dan Hernacki (2013) bahwa metode quantum learning dapat meningkatkan motivasi dan minat belajar seseorang.

\section{SIMPULAN DAN SARAN}

\section{Simpulan}

Hasil uji analisis Mann Whitney U membuktikan bahwa terjadi peningkatan minat belajar IPA setelah diberikan pelatihan quantum learning. Hal ini menunjukkan adanya perbedaan yang signifikan antara sebelum dan sesudah diberikannya perlakuan pada kelompok eksperimen. Dapat disimpulkan bahwa pelatihan quantum learning terbukti meningkatkan minat belajar IPA khususnya di SD Negeri Ponjong II Gunungkidul.

\section{Saran}

Peneliti lain yang ingin mengembangkan diharapkan dapat memperhatikan faktor-faktor yang dapat mempengaruhi variabel tergantung seperti jenis kelamin, tingkat intelegensi, pretesting effect, harapan eksperimenter. serta variasi personal. Jenis kelamin dan tingkat intelegensi merupakan faktor proactive history yang dapat mempengaruhi variabel yang diukur. Adanya soal prates yang dilakukan sebelum pelatihan dapat menyebabkan subjek berusaha untuk mengingat kembali sekaligus mempelajari skala yang diberikan sebelumnya sehingga respon yang terukur bukan merupakan respon dari pemberian pelatihan quantum learning. Adanya harapan eksperimenter dapat menimbulkan bias dalam mencatat data maupun menginterpretasikan data. Variasi personal dapat mempengaruhi variabel tergantung karena karakteristik seseorang cenderung mengalami perubahan pada kurun waktu tertentu. 


\section{Daftar Pustaka}

Abdullah (1998). Pendidikan Teoritis IPA. Jakarta : Kanisius

As'ad M. (2003). Psikologi Industri, Seri Ilmu Sumber Daya Manusia. Jakarta: Liberty

Crow, A. and Crow, L.D. (1994). Psikologi Pendidikan (penerjemah Kasijan). Surabaya: Bina Ilmu

Decenzo dan Robbins. (1999). Human Resource Development, sixth edition. USA: John Willey \& Sons Inc

De Porter, B. \& Hernacki. (2013). Quantum Learning. Bandung : Kaifa

Hamalik. (2012). Proses Belajar Mengajar. Bandung: Bumi Aksara

Hurlock, E.B. (1990). Perkembangan Anak Jilid 2. Jakarta : Erlangga

Latipun. (2011). Psikologi Eksperimen. Malang : UMM Press
Selman, V., Selman, R.C., \& Selman, J. (2003). Quantum Learning: Learn Without Learning. International Busniess \& Economic Research Journal. 4 (2) 47 50

Slameto. (2010). Belajar Dan Faktor-Faktor Yang Mempengaruhinya. Jakarta: Rineka Cipta

Sugihartono. Fathiyah, K.N. Harahap, F. Setiawati, F.A. Nurhayati, S.R. (2007). Psikologi Pendidikan. Yogyakarta: UNY Press

Suryabrata, S (2004). Psikologi Pendidikan.edisi V. Jakarta : Rajawali Press

Sutikno. (2009) Belajar dan Pembelajaran. Bandung : Prospect

Walgito, B. (2002). Pengantar Psikologi Umum. Yogyakarta: Andi Offset 